\title{
Tüketicilerin Maraş Tarhanası Tüketim Davranışlarının Belirlenmesi; Kahramanmaraş İli Örneği
}

\author{
Emine İKIKAT TÜMER Osman Doğan BULUT* Eda SEKER \\ Kahramanmaraş Sütçü İmam Üniversitesi Ziraat Fakültesi Tarım Ekonomisi Bölümü, Kahramanmaraş \\ *(Sorumlu yazar:doganbulut@icloud.com)
}

Geliş Tarihi : 10.04.2017

Kabul Tarihi :11.06.2017

\begin{abstract}
ÖZET : Geleneksel gidalardan biri olan tarhana, üretimi kolay, ucuz, dayanıklı ve en önemlisi besleyici olması nedeniyle Finlandiya, Irak, Macaristan, Türkistan ve Türkiye gibi birçok ülkede yaygın olarak tüketilmektedir. Tarhana tüketimi şekli ülkelerin kültür, zevk ve tercihlerine göre çeșitlilik arz etmekle birlikte genellikle çorba olarak tercih edilmektedir. Türkiye'de özellikle Kahramanmaraş ve çevre illerde tarhana; yaş (firik), çorbalık(kırıntı), çerezlik ve cips olarak tüketilmektedir. Bu çalışmada tüketicilerin sosyo-ekonomik ve demografik özelliklerini, gelir grupları itibariyle Maraș Tarhanasını tüketim miktarlarını, Maraş Tarhanası çeşitlerine göre tüketim tercihlerini ve çerezlik Maraş tarhanasını patates cipsine tercih etme durumu ile ilişkili olan faktörleri belirlemek amaçlanmıştır. Bu amaç kapsamında 2014 yılında Kahramanmaraş ili kent merkezinde 384 tüketici ile bire bir görüşülerek anket yapılmıştır. Elde edilen verilere parametrik ve parametrik olmayan testler uygulanmışıır. Araştırma sonuçlarına göre Maraş tarhanası harcamasının toplam gıda harcaması içerisindeki oranı \%14 olarak hesaplanmıştır. $\mathrm{Bu}$ oran maraş tarhanasının gıda harcamasındaki yerinin önemini göstermektedir. Tüketicilerin \%52.2'sinin çerezlik Maraş tarhanasının yanında cevizi tercih ettiği bulunmuştur. Perakendeci satıcıların bu durumu göz önünde bulundurarak ceviz satışı yapmaları da doğru olacaktır. Ayrıca tüketicilerin \%31.8'i cips formundaki Maraş tarhanasını patates cipsine tercih etmektedirler. Tüketicilere patates cipsinin yerine cips Maraş tarhanası tüketim alışkanlı̆̆ının kazandırılması hem insanların sağlığı açısından faydalı olacaktır hem de il ekonomine katkı sağlayacaktır.
\end{abstract}

Anahtar kelimeler: Maraş tarhanası, firik, cips, tüketim, Kahramanmaraş

\section{Determination of the Maras Tarhana Consumption Behaviours of the Consumers; a Case Study of Kahramanmaras Province}

\begin{abstract}
Tarhana, which is one of the traditional foods, is consumed prevalently in Finland, Iraq, Hungary, Turkistan and Turkey owing to the fact that it is easy to produce, moreover, it is cheap, durable and most importantly, nutritious. Tarhana is generally preferred in soup form in addition to its variety according to countries' culture, lifestyle, pleasure and preference. Tarhana is, generally, consumed in soap form, fresh form (firik), appetizer form and crisp form in Turkey and especially in Kahramanmaras Province. In this study, it is aimed to determine the factors related to consumption of tarhana which can be preferred as fresh, soap, appetizer and crisp. For this purpose, 384 questionnaires were conducted with household by face to face method in Kahramanmaras Province. Parametric and nonparametric analyses were performed to obtained data. As result of the study, the share of expense of Maras tarhana in total expense is calculated as $14 \% .52 .2 \%$ of respondents prefer walnut along with tarhana. Moreover, $31.8 \%$ of respondents prefer crisp tarhana to chips made of potato. Crisp form of Maras Tarhana is a good alternative for potato chips. People who consume potato chips should be canalized to consuming Maras tarhana. By this manner, it can be contributed to health of consumers and Karamanmaras economy.
\end{abstract}

Keywords: Maras tarhana, firik, chips, consumption, Kahramanmaras

\section{GİRIS}

İnsanoğlunun varoluşunu devam ettirebilmesi için çeşitli besin maddelerine ihtiyacı vardır. Besin maddeleri karbonhidratlar, yağlar, proteinler, vitaminler ve mineraller olmak üzere beș temel öğeden oluşur. $\mathrm{Bu}$ temel öğeleri içeren bitkisel ve hayvansal kaynaklı besinlerin günlük olarak dengeli şekilde tüketilmesi, bireylerin ihtiyaç duyduğu enerjiyi alması ve sağlıklı yaşam sürdürmesi açısından büyük önem taşımaktadır. İnsanoğlu geçmişten günümüze kadar kazandığ 1 tecrübelerle çeşitli besin maddelerini bir araya getirerek damak tadına uygun, sağlıklı gıda ürünleri keşfetmiş ve yöresel olarak farklılık gösterebilen bu gıdaların yapımını yeni nesillere öğretmişlerdir.

Yöresel ürünler, üretim bölgesinde istihdam sağlayan, geleneksel üretim biçimleriyle yerel ekonomiyi ayakta tutan, kültürel zenginliğin sembolü haline gelmiş ve üretilen ürünleri geliştirerek gelecek kuşaklara aktaran değerli bir mirastır. Anadolu'da yaklaşık on iki bin yıllık geleneksel ve kültürel birikimin mirası olarak yaklaşı üç bin beş yüz yöresel ürün bulunmakta ve bunların bir bölümü coğrafi işaretlidir (Anonim, 2017).

Coğrafi işaretle tescillenmiş, Kahramanmaraş ilinin yöresel ürünü olan Maraş Tarhanası bitkisel ve hayvansal kaynaklı olup yüksek besleyici özelliğe sahiptir. Yörükoğlu ve Dayısoylu (2016) yaptıkları çalışmada Maraş Tarhanasının fiziksel ve kimyasal bazı özelliklerini incelemişler ve tarhana içeriğinde $\% 90.8$ - \%93.7 oranında kuru madde, \%1.8 - \%5.8 oranında yağ, \%14.4 - \%18.1 oranında protein, \%3.2 - \%5.5 oranında tuz, \%3.3 - \%5.7 oranında selüloz, $\% 72.6$ - \%78.5 oranında karbonhidrat olduğunu tespit etmişlerdir. Ayrıca Maraş tarhanası'nın 3.0 - 
4.2 arasında $\mathrm{pH}$ değeri ve 100 gramının 387.9 $410.3 \mathrm{kcal} / 100$ gr. aralığında enerji değerine sahip olduğunu belirlemişlerdir. Tarhana protein, kalsiyum, demir, sodyum, potasyum, magnezyum, çinko, bakır gibi mineral madde içeriği oldukça yüksek, kolay sindirilebilir bir üründür. A ve $\mathrm{B}$ grubu vitaminleri açısından oldukça zengindir. Üretim sırasında beyaz un yerine tam buğday unu kullanılması tarhananın protein ve vitamin içeriğini artırmaktadır (İbanoğlu vd., 1995).

Maraş tarhanası bütün besleyici özelliğinin yanı sıra kolay saklanabilmesi, depolamaya uygun olması, patates ve misır cipsine tercih edilmesi ve sağlıklı bir besin olması gibi nedenlerle geçmişten günümüze kadar gelmiştir. Önceleri ailelerin kendi imkânlarıyla küçük ölçeklerde ürettiği Maraş tarhanası, bugün modern tesislerde üretilip, bölge gida tüketiminde ihtiyacı karşılamanın yanında marka değeri oluşmuş firmalar ile ülke genelinde satışı yapılarak Kahramanmaraş ilinin kalkınmasına katkı sağlamaktadır.

TS 2282 standardına göre tarhana; buğday unu, kırması, irmik veya bunların karışımı ile yoğurt, biber, tuz, soğan, domates ve tat, koku verici, sağlığa zararsız bitkisel maddelerin karıştırılıp yoğrulduktan ve fermente edildikten sonra kurutulması, ögütülmesi ve elenmesiyle elde edilen besin maddesi olarak tanımlanmaktadır. Bu standarda göre ülkemizde Un tarhanası, Göce tarhanası, İrmik tarhanası ve Karışık tarhana olmak üzere dört çeşit tarhana üretimi yapılmaktadır (TSE, 2004).

Tarhana hemen her bölgede ve özellikle de ev ölçeğinde yapılmakta olan geleneksel gidalarımızdan biridir. Bir çok insanın severek tükettiği tarhana, içeriğindeki hayvansal ve bitkisel kaynaklı maddeler nedeniyle besleyici bir gıdadır (Akbaş ve Coşkun, 2006).

Maraş tarhanası yapımında dövme (buğday yarması) ile yoğurdun yanı sıra ürünün lezzet ve besin değerine katkı sağlayan kekik, çörekotu gibi yardımc1 unsurlar ilave edilmektedir. Üretim yönteminde; buğday yarması kaynamış su ile pişirilir ve tuz ilave edilir. Karışım soğuduktan sonra yoğurt, kekik ve çörekotu ilavesi yapılarak elde edilen karışım mayalanmaya birakılır. Fermantasyonun tamamlanmasının ardından karışım "çı̆̆g” adı verilen hasır türü sergilere serilerek kurutma işlemine tabi tutulur. Kurutma işlemi tamamlandiktan sonra çı̆̆lardan ayrılan tarhana ambalajlanır (Dayısoylu ve ark., 2006; Ötles ve Cagindi, 2006; Coşkun, 2014).

Kahramanmaraş tarhanasının diğer bölgelerdeki tarhanalardan tat ve kalite olarak ayrılmasının en belirgin özelliği olarak temmuz ve ağustos aylarında yapımına başlanması tarhananın bu aylardaki hava şartlarının güzel ve rüzgarlı olmasına bağlanır. Bu aylar içinde Türkiye'de Kahramanmaraş'tan başka hiçbir yörede bulunmayan firik adı verilen (tarhananın tam olarak kurumadan önceki hali) tarhana Kahramanmaraş’a özgü bir çeşittir (Anonim, 2016).

Kuru tarhana çerez, cips ve çorbalık olarak üç farklı şekilde tüketilebilmektedir. Çerezlik tarhana ile cips tarhana arasındaki tek fark kalınlıkları olup cips tarhana çerezlik tarhanaya kıyasla daha ince formdadır. Tarhana cipsi, piyasada kolaylıkla ulaşılan, kızartılarak ya da firınlanarak üretilen diğer cipslere alternatif olarak günün her saatinde tüketilebilen sağlıklı bir çerez çeşididir (Yıldırım ve Güzeler, 2016). Çerezlik, cips ya da firik tarhananın yanında ceviz, badem, findık ve fistık gibi kuruyemişlerin tüketimi tercih edilmektedir. Küçük kırıntı formunda olan çorbalık tarhana ise diğer çeşitlere göre daha kalındır.

Türkiye'de hanehalkı tüketim harcaması incelendiğinde 2015-2016 tarihleri arasında gida harcamasının tüm bütçe içerisindeki payı \%20 olduğu saptanmıştır (TÜİK, 2016). Yapılan çalışmada Kahramanmaraş ilinde gıda harcamasının tüm bütçe içerisindeki payı \%16 olarak bulunmuş ve Maraş tarhanası tüketiminin gıda harcaması içerisindeki payı ise \%14 olarak hesaplanmıştır.

Hanehalkı gıda harcaması içerisinde Maraş tarhanasının payının yüksek olması bölge halkının yöresel ürünlerden biri olan tarhana tüketiminin önemini ortaya koymaktadır.

$\mathrm{Bu}$ çalışmada; Kahramanmaraş ili kent merkezinde tüketicilerin sosyo-ekonomik ve demografik özelliklerini, Maraş tarhanası tüketim tercihlerinin karşılaştırılmasını, Maraş tarhanası çeşitlerine göre tüketim tercihleri ve çerezlik Maraş tarhanasını patatese cipsine tercih etme durumu ile ilişkili olan faktörlerin belirlenmesi amaçlanmıştır.

\section{MATERYAL VE METOT}

Araştırmanın ana materyali Kahramanmaraş ili kent merkezinde ikamet eden tüketicilerle yüz yüze anket yöntemi ile elde edilen verilerden oluşmaktadır. Örnek büyüklügünün hesaplanmasında Oransal Örnekleme yöntemi kullanılmıştır.

$$
n=\frac{N * p *(1-p)}{(N-1) * \sigma_{P}^{2}+p *(1-p)}
$$

Formülde; " $n$ " örnek büyüklüğünü, " $N$ " ana kitledeki birey sayısı," $\sigma_{P}^{2}$ "oranın varyansı ve " $p$ " ise incelenen olayın meydana gelme olasılığıdır. Formülde ana kitle 2015 y1lı Kahramanmaraş il nüfusu 1.089.038 alınmıştır, \%95 güven aralığında ve ortalamadan \%5 sapma değeri kullanılmış ve örnek sayısı 384 olarak hesaplanmıştır.

Veriler tüketicilerin davranışlarını saptamaya yönelik hazırlanmış anket formu ile elde edilmiştir. 
Maraş tarhanası tüketim harcamaları gelir grupları itibariyle incelenmiştir. Daha sonra tüketicilerin sosyo-ekonomik ve demografik özellikleri ile tarhana tüketimi arasındaki ilişki Ki-kare ve F testleri ile incelenmiştir.

\section{BULGULAR}

Araştırma alanında anket yapılan tüketicilerin yaş ortalaması $34.3 \mathrm{y}$ 1l, ailedeki ortalama çocuk sayıs1 3 birey, aylık ortalama gelir 1531 TL/ay, aylık ortalama gida harcaması 245.3 TL/ay ve aylık ortalama tarhana harcaması 35.3 TL/ay olarak hesaplanmıştır (Çizelge 1).

Çizelge 1. Sosyo-ekonomik özellikler

\begin{tabular}{lcccr}
\hline Değişken & Minimum & Maksimum & Ortalama & Std. sapma \\
\hline Yaş (yıl) & 19 & 65 & 34.3 & 9.3 \\
Ailedeki çocuk sayısı & 0 & 6 & 3.0 & 1.1 \\
Gelir (TL) & 500 & 4000 & 1531.0 & 486.7 \\
Gida harcaması (TL/ay) & 50 & 1000 & 245.3 & 119.7 \\
Tarhana harcaması (TL/ay) & 0 & 100 & 35.3 & 12.5 \\
\hline
\end{tabular}

Ankete katılan tüketicilerin \%52.3'ünün erkek, $\% 81.3$ 'ünün evli, \%14.1'inin 26 yaşından küçük, \%22.9'unun 40 yaşından büyük, \%67.2'si ilköğretim okulu mezunu, \%24.2'sinin lise mezunu, \%8.6'sinın üniversite mezunu olduğu ve \%96.1'inin Kahramanmaraşlı olduğu tespit edilmiştir. 3 ve 3 'ten az sayıda çocuğa sahip tüketicilerin oranı \%65.1 ve 3'ten fazla sayıda çocuğa sahip olanların oranı ise \%34.9 olarak hesaplanmıştır. Araştırma bölgesinde cips olarak üretilen Maraş tarhanası daha sağlıklı ve lezzetli olduğu için tüketicilerin belirli bir bölümü tarafindan patates cipsine tercih edilmektedir. Tüketicilerin \%31.8'i çerezlik Maraş tarhana'sını patates cipsine tercih etmektedirler (Çizelge 2).

Çizelge 2. Sosyo-demografik özellikler

\begin{tabular}{|c|c|c|c|}
\hline Değişkenler & Tanımlar & Frekans & $\operatorname{Oran}(\%)$ \\
\hline \multirow{2}{*}{ Cinsiyet } & Erkek & 201 & 52.3 \\
\hline & Kadın & 183 & 47.7 \\
\hline \multirow{3}{*}{ Yaş (yıl) } & $\leq 25$ & 54 & 14.1 \\
\hline & $26-40$ & 242 & 63.0 \\
\hline & $41 \leq$ & 88 & 22.9 \\
\hline \multirow{3}{*}{ Eğitim Durumu } & İlköğretim & 258 & 67.2 \\
\hline & Lise & 93 & 24.2 \\
\hline & Üniversite & 33 & 8.6 \\
\hline \multirow{2}{*}{ Memleket } & Kahramanmaraş & 369 & 96.1 \\
\hline & Diğer & 15 & 3.9 \\
\hline \multirow{2}{*}{ Medeni Durum } & Evli & 312 & 81.3 \\
\hline & Bekâr & 72 & 18.7 \\
\hline \multirow{3}{*}{ Ailedeki Çocuk Sayısı } & $\leq 2$ & 129 & 33.6 \\
\hline & $\overline{3}$ & 121 & 31.5 \\
\hline & $4 \leq$ & 134 & 34.9 \\
\hline \multirow{2}{*}{$\begin{array}{l}\text { Çerezlik Maraş } \\
\text { Tarhanasını patates } \\
\text { cipsine tercih etme }\end{array}$} & Tercih eden & 122 & 31.8 \\
\hline & Tercih etmeyen & 262 & 68.2 \\
\hline
\end{tabular}

Tüketicilerin kuru veya yaş Maraş tarhanası (firik) yanında kuruyemiş olarak \%52.2'sinin ceviz, \%26.7'sinin badem, \%17.3'ünün fistık ve \%3.6'sinın ise fındık tercih ettiği saptanmıştır (Çizelge 3).
Kahramanmaraş Meslek Yüksekokulu Öğrencileri, tarhananın yanında tercih ettikleri kuruyemiş çeşitlerini ceviz (\%29.9), fistık (\%26.6) ve badem (\%23.2) olarak sıralamışlardır (Kaya vd.,2015). 
Çizelge 3. Tüketicilerin kuru veya yaş Maraş tarhanası yanında kuruyemiş tercihleri

\begin{tabular}{lcc}
\hline Kuruyemiş Çeşidi & Frekans & Oran(\%) \\
\hline Ceviz & 199 & 52.3 \\
Badem & 102 & 26.7 \\
Fistık & 66 & 17.3 \\
Findık & 14 & 3.7 \\
\hline
\end{tabular}

Çizelge 4'te, tüketiciler gelir düzeyleri itibariyle 3 gruba ayrılmış olup, gıda ve Maraş tarhanasına yaptıkları harcamalar tek yönlü varyans analizi yapılarak incelenmiştir. 1. Gelir grubu aylık 1250 TL'den daha az gelire sahip tüketiciler, 2. Gelir grubu aylık $1250 \mathrm{TL}$ ve 1950TL arasinda gelire sahip tüketiciler ve 3. Gelir grubu ise aylık $2000 \mathrm{TL}$ ve üzeri gelire sahip tüketicilerden oluşmaktadır.

Tek yönlü varyans analizi (ANOVA) normal dağılımlı bir seride üç ve daha fazla bağımsız ortalama arasındaki farkın manidarlığının hesaplanmasında kullanılır. ANOVA tek başına üç veya daha fazla grubun aritmetik ortalamalarını kümülatif olarak karşılaştırır; bu karşılaştırmalardan en az birisi anlamlı olduğunda ANOVA sonucu da anlamlı bulunur (Otrar, 2016).
Analiz sonucuna göre 1. Gelir grubundaki tüketicilerin aylık gıda harcaması ortalama olarak 199.4 TL, 2. Gelir grubundaki tüketicilerin 241.4 TL ve 3. Gelir grubundaki tüketicilerin ise $250.4 \mathrm{TL}$ olduğu saptanmıştır. Aylık Maraş tarhanasına yapılan harcama 1. Gelir grubunda 29.1 TL, 2. Gelir grubunda $36.4 \mathrm{TL}$ ve 2. Gelir grubunda ise $35.5 \mathrm{TL}$ olarak tespit edilmiştir. Yapılan F-testi sonucu tüketicilerin geliri ile aylık gıda harcaması ve Maraş tarhanasına yapılan harcama miktarı ortalamaları arasında istatistiksel olarak anlamlı bir fark olduğu gözlenmektedir $(\mathrm{P}=0.000)$. Hane halk1 gelir düzeyi arttıkça aylık gıda harcaması ve Maraş tarhanasına yapılan harcama değer olarak artmaktadır.

Çizelge 4. Gelir dağılımı içerisinde aylık gıda ve Maraş tarhanası harcaması

\begin{tabular}{|c|c|c|c|}
\hline Gelir grubu & $\begin{array}{c}\text { Gida } \\
\text { Harcaması (TL/ay) } \\
\text { (1) }\end{array}$ & $\begin{array}{c}\text { Maraş Tarhanasına } \\
\text { Yapılan Harcama (TL/ay) } \\
\text { (2) } \\
\end{array}$ & $\begin{array}{l}\text { Oran } \\
(\%) \\
(2 / 1)\end{array}$ \\
\hline 1.Gelir grubu & 199.4 & 29.1 & 14.5 \\
\hline 2.Gelir grubu & 241.4 & 36.4 & 15.0 \\
\hline 3.Gelir grubu & 353.9 & 42.1 & 16.7 \\
\hline Ortalama & 250.8 & 35.5 & 14.1 \\
\hline $\begin{array}{l}\text { F değeri } \\
\text { (p-değeri) }\end{array}$ & $\begin{array}{l}35.428 \\
(0.000)\end{array}$ & $\begin{array}{l}21.490 \\
(0.000)\end{array}$ & $\begin{array}{c}4.083 \\
(0.018)\end{array}$ \\
\hline
\end{tabular}

Karar: $\mathrm{H}_{0}$ hipotezi reddedilir, yani gelir grupları itibariyle gıda harcamasında ve Maraş tarhanasına yapılan harcamada fark vardır.

Ankete katılan tüketiciler ylllık ortalama olarak $179.4 \mathrm{~kg}$ firik, $19.8 \mathrm{~kg}$ çerezlik, $15.5 \mathrm{~kg}$ çorbalık ve $12.9 \mathrm{~kg}$ cips formunda Maraş tarhanasını tüketmektedir. Hane halkları yıllık ortalama olarak toplam $227.6 \mathrm{~kg}$ Maraş tarhanası tüketmektedir.
Toplam tüketim içerisinde en büyük pay \%78.8'lik oranla firik formundaki Maraş tarhanasına ait olup bunu \%19.8'lik pay ile çerezlik Maraş tarhanası takip etmektedir (Çizelge 5).

Çizelge 5. Hane halklarında Maraş tarhanası çeşitlerine göre tüketim miktarları

\begin{tabular}{lcc}
\hline Tarhana Çeşidi & Tüketim Miktarı (kg/yıl) & $\begin{array}{c}\text { Toplam Maraş Tarhanası Tüketimindeki } \\
\text { Oranı (\%) }\end{array}$ \\
\hline Firik & 179.4 & 78.9 \\
Çerezlik & 19.8 & 8.7 \\
Çorbalık & 15.5 & 6.8 \\
Cips & 12.9 & 5.6 \\
\hline Toplam & 227.6 & 100 \\
\hline
\end{tabular}

Tüketicilerin çerezlik Maraş tarhanasını patates cipsine tercih etme durumları ile sosyo-ekonomik ve demografik özellikleri arasındaki ilişkiyi ortaya koymak için nan-parametrik testlerden olan ki-kare testi verilere uygulanarak değerlendirme yapılmıştır.

Ki-kare testi, niteliksel (kesikli-kategorik) olarak tanımlanan değişkenlerde kullanılır. Ayrıca, 
ölçümle tanımlanan sürekli değişkenler de, belli bir değerden az veya çok olarak nitelendirilerek kesikli değişkene dönüştürülebilir ve dönüştürülen bu değişkene de ki-kare testi uygulanabilir. Ki-kare testi, gözlenen frekanslar ile beklenen frekanslar arasındaki farkın istatistiksel olarak anlamlı olup olmadığı temeline dayanan bir testtir (Kılıç, 2016).

Yapılan ki-kare testinye tüketicilerin cinsiyet, yaş, eğitim düzeyi, gelir seviyesi ve ailedeki çocuk sayısı ile çerezlik Maraş tarhanasını patates cipsine tercih etme durumu karşılaştırılmıştır. Çerezlik Maraş tarhanasını patates cipsine tercih etme durumu ile yaş, eğitim düzeyi, gelir seviyesi ve çocuk sayısı arasında farklı önem seviyelerinde istatistiksel olarak anlamlı ilişki olduğu tespit edilmiştir.

Tüketicilerin çerezlik Maraş tarhanasını patates cipsine tercih etme durumları ile yaş grupları karşılaştırıldığında 30 yaşından küçük tüketicilerin \%38.9'u, 31-45 yaş arasındakilerin \%33.9'u ve 46 yaşından büyük olanların \%21.6'sı çerezlik Maraş tarhanasını patates cipsine tercih etmektedir. Yaş grupları itibariyle Maraş tarhanasını patates cipsine tercih etme durumları arasında istatistiksel olarak anlamlı bir ilişki gözlemlenmiştir $\quad(p<0.10)$. Tüketicilerin yaşı arttıkça çerezlik Maraş tarhanasını patates cipsine tercih etme oranı azalmaktadır. Bu durum büyük yaş grubundaki tüketicilerin patates cipsi tüketmeyi daha çok tercih ettiklerini göstermektedir. Tüketicilerin eğitim düzeyleri ile Maraş Tarhanasını patates cipsine tercih durumları arasında istatistiki olarak anlamlı bir ilişki bulunmuştur. Eğitim düzeyi arttıkça çerezlik Maraş tarhanasinı patates cipsine tercih etme durumu artmıştır. Bu durum eğitim seviyesindeki artış ile tüketicilerin Maraş tarhanasının faydaları hakkında diğer bir ifadeyle patates cipslerinin zararları hakkında daha fazla bilgi sahibi olmalarından kaynaklanmaktadır. Gelir gurupları ile tercih durumları incelendiğinde ise yapılan test sonucu gruplar arasında anlamlı bir fark olduğu gözlenmektedir. Gelir düzeyi arttıkça çerezlik Maraş tarhanasinı patates cipsine tercih etme durumu azalmaktadır. Gelir artışı ile tüketiciler yöresel ürün olan çerezlik Maraş tarhanasını bırakıp alternatif olarak görülen patates cipsini tercih ettiği görülmektedir (Çizelge 6).

Çizelge 6. Sosyo-ekonomik ve demografik özelliklere göre çerezlik Maraş tarhanasını patates cipsine tercih etme durumu

\begin{tabular}{|c|c|c|c|c|}
\hline Değişkenler & Tanımlar & $\begin{array}{c}\text { Tercih etmeyen } \\
(\%)\end{array}$ & Tercih eden (\%) & $\begin{array}{c}\text { Toplam } \\
(\%)\end{array}$ \\
\hline \multirow{3}{*}{ Cinsiyet } & Kadın & 71.0 & 29.0 & 100.0 \\
\hline & Erkek & 65.7 & 34.3 & 100.0 \\
\hline & Toplam & 68.2 & 31.8 & 100.0 \\
\hline Ki kare: 1.273 & p: 0.259 & & & \\
\hline \multirow{4}{*}{ Yaş grupları } & $\leq 30$ & 61.1 & 38.9 & 100.0 \\
\hline & $31-45$ & 66.1 & 33.9 & 100.0 \\
\hline & $46 \leq$ & 78.4 & 21.6 & 100.0 \\
\hline & Toplam & 68.2 & 31.8 & 100.0 \\
\hline Ki kare: 5.968 & p: $0.051^{*}$ & & & \\
\hline \multirow{4}{*}{ Eğitim Düzeyi } & İlköğretim & 73.3 & 26.7 & 100.0 \\
\hline & Lise & 66.7 & 33.3 & 100.0 \\
\hline & Üniversite & 33.3 & 66.7 & 100.0 \\
\hline & Toplam & 68.2 & 31.8 & 100.0 \\
\hline Ki kare: 21.650 & $\mathrm{p}: 0.000 * * *$ & & & \\
\hline \multirow{4}{*}{ Gelir grupları } & 1.Gelir grubu & 53.1 & 46.9 & 100.0 \\
\hline & 2.Gelir grubu & 70.8 & 29.2 & 100.0 \\
\hline & 3.Gelir grubu & 69.8 & 30.2 & 100.0 \\
\hline & Toplam & 65.4 & 34.6 & 100.0 \\
\hline Ki kare: 9.138 & p: $0.010^{* *}$ & & & \\
\hline \multirow{4}{*}{ Çocuk sayısı } & $\leq 2$ & 62.0 & 38.0 & 100.0 \\
\hline & 3 & 66.9 & 33.1 & 100.0 \\
\hline & $4 \leq$ & 75.4 & 24.6 & 100.0 \\
\hline & Toplam & 68.2 & 31.8 & 100.0 \\
\hline Ki kare: 5.545 & $\mathrm{P}: 0.063^{*}$ & & & \\
\hline
\end{tabular}




\section{SONUC VE ÖNERILER}

$\mathrm{Bu}$ çalışmada Kahramanmaraş ili kent merkezinde tüketicilerin sosyo-ekonomik ve demografik özelliklerini, gelir grupları itibariyle Maraş tarhanasını tüketim miktarlarını, Maraş tarhanası çeşitlerine göre tüketim tercihlerini ve çerezlik Maraş tarhanasını patatese cipsine tercih etme durumu ile ilişkili olan faktörleri belirlemek amaçlanmıştır. Bu amaçla Kahramanmaraş ili kent merkezinde 384 tüketici ile anket yapılmıştır.

Tüketicilerin geliri arttıkça Maraş tarhanasına yapılan harcamaları da artmaktadır. Yağ, karbonhidrat, protein ve selüloz bakımından zengin, dövme (buğday yarması) ve yoğurttan yapılan, besleyici özelliği yüksek olan Maraş tarhanası'nın tüketimini artırmak için düşük gelirli tüketicilere Maraş tarhanası'nın bu özellikleri anlatılmalıdır. Ülke genelinde tüketiminin artırılması için de Maraş tarhanası'nın tanıtımı yapılmalıdır. Özellikle patates cipsine ikame edilebilecek bir ürün olduğu vurgulanmalıdır. Bunun yanı sıra cips tarhananın tanıtıma patates cipsinin en fazla tüketildiği ve genç nüfusun yoğun olduğu illerden başlanabilir.

Eğitim düzeyi ile çerezlik Maraş tarhanasını patates cipsine tercih etme durumu arasında aynı yönlü bir ilişki olduğu saptanmıştır. Eğitim seviyesi yükseldikçe yöresel ürün olan çerezlik Maraş tarhanası tüketiminde artış olmaktadır. Eğitim seviyesi düşük tüketicilerin patates cipsini tercih ettiği gözlemlenmiştir. Bu tercihin bireylerin sağlığ1 açısından doğru bir alışkanlık olmadığı bu gruptaki tüketicilere bilgilendirme çalışması yapılarak anlatılmalıdır. Patates cipslerinin kanser, obezite, damar tıkanıklıkları, alzheimere gibi bir çok hastalığa neden olduğu uzmanlar tarafindan belirtilmektedirler. Maraş tarhanasının insan sağlığına olumlu etkileri hakkında tüketiciler bilinçlendirilerek tüketimlerini bu yönde değiştirmeleri sağlanabilir.

\section{KAYNAKLAR}

Akbaş, Ş., Coşkun, H., 2006. Tarhana üretimi ve özellikleri üzerine bir değerlendirm. Türkiye 9. Gıda Kongresi; 24-26 Mayıs 2006, Bolu.

Anonim. 2016. Web adres: https://kahramanmaras.bel.tr/marastarhanasi (Erişim: 3.Mart.2017)

Anonim. 2017. Web adres: http://www.tarimdunyasi.net/2016/10/26/anadolununmirasiyoresel-urunler (Erişim: 14.Mart.2017)

Coşkun, F. 2014. Tarhananın tarihi ve Türkiye'de tarhana çeşitleri. Gıda Teknolojileri Elektronik Dergisi, Cilt: 9, No: 3, 2014 (69-79).

Dayısoylu K., S, İnanç AL, Duman AD, Gezginç Y, Özsisli B, 2002. Model Kahramanmaraş tarhanası. Hububat Ürünleri Teknolojisi Kongre ve Sergisi, 3-4 Ekim, Gaziantep, (485491).

Dayısoylu, K., S., Yörükoğlu, T.,. 2016. Yöresel Maraş tarhanasının fonksiyonel ve kimyasal bazı özellikleri. Atatürk Üniv. Ziraat Fak. Derg., 47 (1): 53-63, 2016

İbanoğlu, S., Ainsworth, P., Wilson, G. ve Hayes, G.D., "The effect of fermentation conditions on the nutrients and acceptability of tarhana", Food Chemistry, Volume 53 (2), s.143 147, 1995

Kaya, E., Şekkeli, Z., H., Tekin, F., B., Erdem, T., K., 2015 Kahramanmaraș Meslek Yüksekokulu öğrencilerinin Maraș tarhanası tüketim biçimlerinin belirlenmesi. KSÜ Doğa Bil. Derg. 18(4), 1015.

K1lıç, S. 2016. İstatistiksel İfadeyle Ki-kare Testi. Journal of Mood Disorders (JMOOD, 6 (3):180-2

Otrar, M., 2016. Tek Yönlü Varyans Analizi (ANOVA). http://mustafaotrar.net/istatistik/tek-yonlu-varyans-analizianova (Web erişim: 2.Nisan.2017)

Ötles S, Cagindi Ö, 2006. Cereal based functional foods and nutraceutical. Acta Sci. Pol., Technol. Aliment., 5(1): 107112.

TSE, TS 2282, “Tarhana Standardı”, Türk Standartlar Enstitüsü, Ankara, 2004.

TÜIK, 2016 Hanehalkı Tüketim Harcaması. http://www.tuik.gov.tr/PdfGetir.do?id=21580 (Erişim: 18.Mart.2017)

Yıldırım, Ç. ve Güzeler, N. 2016. Tarhana Cipsi, Nevşehir Bilim ve Teknoloji Dergisi TARGID Özel Sayı 1-8 2016 DOI: 10.17100/nevbiltek.16158. 